\title{
INDIVÍDUOS “FORA DE LUGAR”: o caso dos(as) docentes negros(as) nas relações de trabalho na Universidade de Brasília
}

\section{Verônica Maria da Silva Gomes}

Curso: Mestrado em Sociologia

Data de defesa da dissertação: 10 de março de 2004

Orientadora: $\operatorname{Prof}^{a} \operatorname{Dr}^{a}$ Maria Salete Kern Machado

\section{Resumo}

Tendo como campo a Universidade de Brasília (UnB) - onde menos de $1 \%$ do pessoal docente é negro - esta pesquisa qualitativa buscou verificar como um grupo de 14 docentes negros, atuando em um locus onde raramente são encontrados em posição de prestígio, vivenciam as experiências de discriminação; como reagem a elas na sua vida cotidiana e no ambiente de trabalho e se existe mobilização de estratégias individuais e/ou coletivas de defesa que os auxiliem a superar o sofrimento decorrente dessas experiências de discriminação nas relações de trabalho. Essas estratégias passariam pela construção de mecanismos defensivos individuais para enfrentamento da discriminação racial no dia-a-dia acadêmico e fariam parte das estratégias ligadas à organização do trabalho.

A análise qualitativa desse objeto gerou as seguintes considerações: 1) alvo de estigma negativo presente no imaginário social brasileiro, os docentes negros enfocados nesta pesquisa, situamse "fora de lugar", fora do locus em que a sociedade os aceitaria mais facilmente; 2) buscaram resgatar as suas próprias identidades, superando o susto, o medo e a vergonha, introjetando uma auto-estima positiva que os estimulou a prosseguir e a transpor barreiras; 3) para 
superar o sofrimento nas relações de trabalho, engendraram mecanismos estratégicos de defesa individuais para estabeleceram o mínimo de convivência e serem respeitados nesse lugar "proibido".

Dentre as formas mais comuns de estratégia de defesa desenvolvidas pelos(as) docentes, encontram-se: a resposta defensiva antecipada; o retraimento ou a reação de forma agressiva que pode resultar em respostas indesejáveis e no estabelecimento de uma interação violenta. Para este grupo, não existem estratégias defensivas coletivas. Suas diferenças são diluídas pelo sistema, que cria o anonimato e os individualiza no sofrimento.

Palavras-chave: docentes negros(as), problemática racial brasileira, discriminação racial, discriminação nas relações de trabalho, sofrimento nas relações de trabalho, mobilização de estratégias individuais de defesa. 